\title{
MIR4457 Gene
}

National Cancer Institute

\section{Source}

National Cancer Institute. MIR4457 Gene. NCI Thesaurus. Code C118121.

This gene may plays role in gene silencing. 